Binninger M., Dlouhy J., Steuer, D. and Haghsheno S. (2017). “Adjustment Mechanisms for Demandoriented Optimisation in Takt Planning and Takt Control.” In: LC3 2017 Volume II - Proceedings of the 25th Annual Conference of the International Group for Lean Construction (IGLC), Walsh, K., Sacks, R.,

Brilakis, I. (eds.), Heraklion, Greece, pp. 613-620. DOI: https://doi.org/10.24928/2017/0086

\title{
ADJUSTMENT MECHANISMS FOR DEMAND- ORIENTED OPTIMISATION IN TAKT PLANNING AND TAKT CONTROL
}

\author{
Marco Binninger ${ }^{1}$, Janosch Dlouhy ${ }^{2}$, Dominik Steuer ${ }^{3}$, and Shervin Haghsheno ${ }^{4}$
}

\begin{abstract}
Takt Planning and Takt Control is a crucial method utilised in Lean Construction. It has however recently undergone criticism due to its scheduling rigidity during construction and hindrance to adjustments during the course of a project. Generating a takted time plan is done at the beginning of a project and is not necessarily fixed during its whole lifetime. The Takt Plan offers a framework for a stable project execution and increased transparency throughout the construction process. In case of disruptions or changes of the framework conditions, the consequences can be visualised and managed in a targeted way. The Takt Plan can then be adjusted in accordance. The long-term goal is to reduce the required adjustments and increase the accuracy of predictions. This is done by increasing the experience of practitioners within the method by applying it and through a greater control over the construction process. During the execution of a project various adjustment mechanisms can be applied. These adjustment mechanisms can be flexibly implemented depending on the circumstances and the desired approach. The aim of this article is to introduce and categorise possible adjustment mechanisms within the scope of Takt Planning and Takt Control. In total 31 adjustment mechanisms are identified. Based on the experience of the authors, their effects and consequences are additionally presented. Using examples, a selection of the five adjustment mechanisms most used in current projects are explained in detail.
\end{abstract}

Keywords: Production Schedule, Takt Planning, Takt Time, Takt Control, Adjustment Mechanism

\section{INTRODUCTION}

Construction sites are dynamic systems, which require continuous adjustments to their schedule (Park et al. 2003, p. 213). Hao et al. (2008, p. 387-389) underline this fact and assume that project changes and adjustments occur during all project phases. The Takt Planning and Takt Control method provides a flexible production system for construction sites, as mentioned in "Technical Takt Planning and Control in Construction" (Binninger et al. 2017). This is also based on the practical example in the paper of Dlouhy et al. (2016). However, this method is sometimes considered rigid and inflexible. The Takt Plan set during a collaborative workshop serves as a framework for planning and controlling construction processes for everything from design to execution. The Takt time serves as a standardised timeframe, which sets the construction pace for

Research Fellow, Karlsruher Institute of Technology, Germany, marco.binninger@kit.edu

Research Fellow, Karlsruher Institute of Technology, Germany, janosch.dlouhy@kit.edu

Employee, BMW AG, Germany, dominik.steuer@bmwgroup.com

Professor, Karlsruher Institute of Technology, Germany, shervin.haghsheno@kit.edu 
individual trades. The structure provided by the standardisation enhances predictability and routine in the processes. Alternating contingencies, which are typical to the construction industry, can be dealt with using Takt time (Syben 2014, p. 82-88). A continuous improvement process (CIP) cannot be implemented without using any standards (Zimmermann et al. 2012, p. 22).

Construction schedules have limited value if construction processes are not controlled properly (Seppänen 2012). The Takt plan, as a specialised form of a schedule generated for each project, offers the flexibility that is necessary to adjust to project changes in various forms. Other options to generate a production plan are not part of this paper. The here used method of Takt planning and Takt control differs in its core principles on how the Takt time is defined compared to the methods Takt time planning by Tommelein und Frandson and the LBMS, therefore new terms and adjustment mechanisms are developed.

The mechanisms described in this article enable a dynamic execution of construction processes as required by Park und Pena-Mora (2003).

\section{STRUCTURE OF THIS PAPER}

The first part of this article describes the efficiency and flexibility gained by applying the method of Takt Planning and Takt Control in a case study. By defining and calculating Standard Space Units (SSU) a production plan can be developed within a short period of time (Haghsheno et al. 2015). This production plan provides a framework for planning and execution of construction processes. The method of Takt planning offers the flexibility to react to changes on site with the support of the mechanisms described in the second part of this article. The matrix in section 3.2 evaluates the mechanisms in terms of their effect on the construction process and illustrates the frequency of application in the projects. In the third section five selected mechanisms are presented and described through a case study. It is not part of the paper to explain different impacts and give a guideline how these mechanisms are treated in practise.

\section{CASE Study Of taKt PlanNing}

The selected case study considers a care facility for elderly with three nearly identical floors. The building covers a surface of $1450 \mathrm{~m} 2$ over three levels with 75 rooms of a similar size. Figure 1 shows a floor plan.

An initial analysis divides the building into functional clusters. In this case these are the habitable rooms, corridor, common rooms, stairwells, facade and shell. Consequently the SSU for each function cluster is determined (Haghsheno et al. 2016). Here the focus is on the fit-out of the habitable rooms, as shown in Figure 1. The common rooms (red) and corridor (blue) can in this case also be categorized as habitable rooms since their construction processes do not greatly differ. Only the colours of the floors and walls differ, which has virtually no impact on the processes. Compared to typical preparation work for construction projects, takting requires only the work sequence for one SSU and the relative work packages for that unit. 


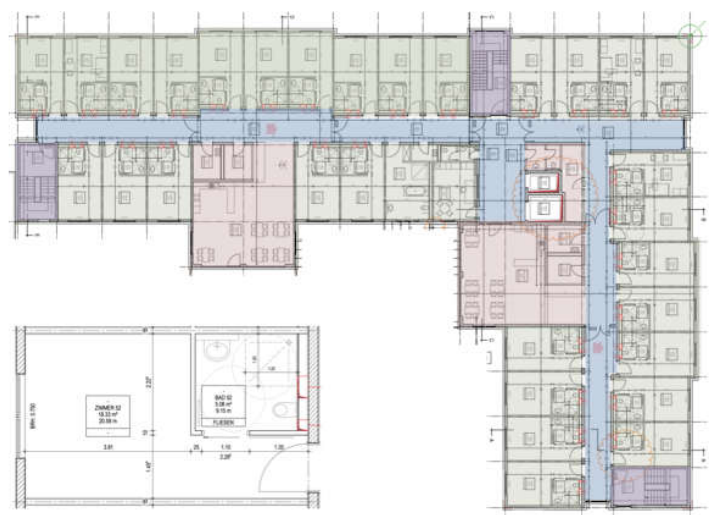

Figure 1: Floor plan using colours to show functional clusters to define the interior fit-out and the SSU of a habitable room.

Representatives from all trades participating in the process develop this sequence during a workshop. Here 16 work packages (waggons) with a total of over 130 working steps are defined. In the second step of Takt Planning the volume per SSU for each working step is determined and multiplied by a performance factor. As a result in a work distribution diagram is created for each work package within the SSU (Binninger et al. 2016). In this case the Takt time is defined as one week. The various adjustment mechanisms such as adaptation of work crew sizes or allocation of SSUs to a particular Takt area is harmonised using the work distribution diagram. The process to generate an initial Takt plan takes only a few hours. Here approximately six habitable rooms are combined into one Takt area along with corridors and living rooms. This particular combination results in 17 Takt areas. The selected size of the Takt areas is between 170 and $200 \mathrm{~m} 2$. The guidelines for Takt size proposed by Haghsheno et al. (2016) are applied in this instance.

Subsequently the production plan along with associated costs, crew sizes and material flows is approved and agreed upon by all participants. At this early planning stage, adjustment mechanisms such as reducing crew sizes, incorporating required buffers, adapting interfaces, parallelising trades or accelerating the Takt plan can be used. Likewise, there are additional adjustment mechanisms for later control. The established adjustment mechanisms from practice are listed and categorised in the section 3.3.

\subsection{Description and categorisation of the identified adjustment mechanisms}

The identified adjustment mechanisms identified are named in this section and it is determined whether these are primarily used in Takt Planning, Takt Control or both. In many cases this is not a trivial categorisation. The evaluation is based on the authors' practical experience. Furthermore, every adjustment mechanism is briefly described as well as the associated effect on the construction process. Based on the frequency of usage, the adjustment mechanisms are allocated into three categories and described in greater detail for further evaluation. Category A represents mechanisms, which according to the authors' evaluation has been used in over 30 cases. Category B mechanisms were used in five to 30 cases, and category $\mathrm{C}$ represents mechanisms used in less than five cases. The categorisation can be seen in the following table.

Table 1: Categorisation of adjustment mechanism 


\begin{tabular}{|c|c|c|c|c|c|c|}
\hline \# & Name & 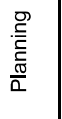 & 홀 & 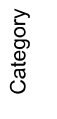 & Description & Effect \\
\hline 1 & $\begin{array}{l}\text { Decoupling of } \\
\text { Takt areas }\end{array}$ & $X$ & $\mathrm{X}$ & A & $\begin{array}{l}\text { Reorganising the sequence for } \\
\text { completing Takt areas }\end{array}$ & $\begin{array}{l}\text { Change in the order areas are } \\
\text { completed }\end{array}$ \\
\hline 2 & Empty waggon & $X$ & $X$ & A & $\begin{array}{l}\text { Planning of buffer times (slack); for } \\
\text { example drying-out periods }\end{array}$ & $\begin{array}{l}\text { Visualisation of required buffer; } \\
\text { lengthening of the construction } \\
\text { time }\end{array}$ \\
\hline 3 & $\begin{array}{l}\text { Phase } \\
\text { interlinking }\end{array}$ & $X$ & & A & $\begin{array}{l}\text { Different process phases require } \\
\text { different sizes for Takt areas. } \\
\text { Adjustment for these differences } \\
\text { results in efficiencies. }\end{array}$ & $\begin{array}{l}\text { Optimisation of the construction } \\
\text { process }\end{array}$ \\
\hline 4 & Soft start & $X$ & & $A$ & $\begin{array}{l}\text { Delaying following trains, if more than } \\
\text { one train is used. This allows learning } \\
\text { from the starting train. }\end{array}$ & $\begin{array}{l}\text { Lengthening of the construction } \\
\text { time, stabilisation of site } \\
\text { processes }\end{array}$ \\
\hline 5 & Train stoppage & & $X$ & A & $\begin{array}{l}\text { Stopping the construction process } \\
\text { due to a problem }\end{array}$ & Longer duration of construction \\
\hline 6 & $\begin{array}{l}\text { Combining } \\
\text { handover times }\end{array}$ & $X$ & $X$ & $B$ & $\begin{array}{l}\text { Arranging the handover by combining } \\
\text { Takt areas to lager areas. }\end{array}$ & $\begin{array}{l}\text { Bundling of Takt areas for } \\
\text { handover }\end{array}$ \\
\hline 7 & $\begin{array}{l}\text { Coupling into and } \\
\text { onto }\end{array}$ & $\mathrm{X}$ & $X$ & $B$ & $\begin{array}{l}\text { Adding or Removing waggons to } \\
\text { change the process sequence. }\end{array}$ & $\begin{array}{l}\text { Lengthening of the construction } \\
\text { time }\end{array}$ \\
\hline 8 & Jumpers & $X$ & $X$ & $B$ & $\begin{array}{l}\text { Using flexible labor to deal with peaks } \\
\text { in required work }\end{array}$ & $\begin{array}{l}\text { Harmonisation of the work } \\
\text { process }\end{array}$ \\
\hline 9 & $\begin{array}{l}\text { Split of train } \\
\text { order }\end{array}$ & $x$ & $X$ & $B$ & $\begin{array}{l}\text { Splitting the construction sequence, } \\
\text { because conditions demand for } \\
\text { extended process durations. }\end{array}$ & $\begin{array}{l}\text { Lengthening of the construction } \\
\text { time }\end{array}$ \\
\hline 10 & $\begin{array}{l}\text { Takt time } \\
\text { reduction }\end{array}$ & $X$ & $X$ & $B$ & Reducing the Takt time & $\begin{array}{l}\text { Harmonisation of the process } \\
\text { sequence; shortening of the } \\
\text { throughput time }\end{array}$ \\
\hline 11 & $\begin{array}{l}\text { Takt time } \\
\text { increase }\end{array}$ & $X$ & $X$ & $B$ & Extending the Takt time & $\begin{array}{l}\text { Harmonisation of the process } \\
\text { sequence; lengthening of the } \\
\text { throughput time }\end{array}$ \\
\hline 12 & Train split & $X$ & $X$ & $B$ & $\begin{array}{l}\text { Paralleling multiple trains with similar } \\
\text { sequences to pass the construction } \\
\text { site. }\end{array}$ & $\begin{array}{l}\text { Shortening of the construction } \\
\text { time }\end{array}$ \\
\hline 13 & $\begin{array}{l}\text { Waggon } \\
\text { acceleration }\end{array}$ & $X$ & $X$ & $B$ & $\begin{array}{l}\text { Ensuring a stable Takt time by } \\
\text { optimising a waggon in detail }\end{array}$ & $\begin{array}{l}\text { Harmonisation of the process } \\
\text { sequence (Levelling); } \\
\text { shortening of construction time }\end{array}$ \\
\hline 14 & $\begin{array}{l}\text { Waggon } \\
\text { overlapping }\end{array}$ & $\mathrm{X}$ & $X$ & $B$ & $\begin{array}{l}\text { Following waggons start before the } \\
\text { preceding waggon is completed }\end{array}$ & $\begin{array}{l}\text { Optimisation of the process } \\
\text { sequence }\end{array}$ \\
\hline 15 & $\begin{array}{l}\text { Waggon } \\
\text { parallelisation }\end{array}$ & $x$ & $X$ & $B$ & Completing waggons in parallel & $\begin{array}{l}\text { Optimisation of the process } \\
\text { sequence }\end{array}$ \\
\hline 16 & Hard start & $\mathrm{X}$ & & $\mathrm{B}$ & $\begin{array}{l}\text { Starting multiple waggons at the } \\
\text { same time }\end{array}$ & $\begin{array}{l}\text { Shortening of the construction } \\
\text { time }\end{array}$ \\
\hline 17 & $\begin{array}{l}\text { Inserting fixed } \\
\text { buffers }\end{array}$ & $\mathrm{X}$ & & $\mathrm{B}$ & $\begin{array}{l}\text { Planning slack at the end of a } \\
\text { sequence/train }\end{array}$ & $\begin{array}{l}\text { Slack is built in to stabilise the } \\
\text { construction process }\end{array}$ \\
\hline 18 & KIT Move & $X$ & & $B$ & $\begin{array}{l}\text { Combining multiple work packages to } \\
\text { use the full Takt time in a waggon. }\end{array}$ & $\begin{array}{l}\text { Harmonising of the process } \\
\text { sequence; shortening of the } \\
\text { construction time }\end{array}$ \\
\hline 19 & Shunting yard & $\mathrm{X}$ & & $B$ & Utilizing available process sequences & Changing construction site \\
\hline
\end{tabular}




\begin{tabular}{|c|c|c|c|c|c|c|}
\hline & & & & & & sses \\
\hline 0 & $\begin{array}{l}\text { Splitting Takt } \\
\text { areas }\end{array}$ & $x$ & $(\mathrm{X})$ & B & Reducing the size of Takt areas & $\begin{array}{l}\text { Harmonisation of the process } \\
\text { sequence }\end{array}$ \\
\hline & $\begin{array}{l}\text { Takt area } \\
\text { enlargement }\end{array}$ & $x$ & $(\mathrm{X})$ & B & Increasing the size of Takt areas & $\begin{array}{l}\text { Harmonisation of the process } \\
\text { sequence; lengthening of the } \\
\text { throughput time }\end{array}$ \\
\hline & $\begin{array}{l}\text { Waggon } \\
\text { subcontracting }\end{array}$ & $x$ & $(\mathrm{X})$ & B & $\begin{array}{l}\text { Completing individual waggons with } \\
\text { subcontractors }\end{array}$ & $\begin{array}{l}\text { Stabilisation of construction site } \\
\text { processes }\end{array}$ \\
\hline & $\begin{array}{l}\text { Multiple train } \\
\text { levelling }\end{array}$ & & $\mathrm{x}$ & B & $\begin{array}{l}\text { Using multiple trains to increase } \\
\text { efficiency within workers and trades }\end{array}$ & $\begin{array}{l}\text { Stabilisation and optimisation of } \\
\text { the construction process }\end{array}$ \\
\hline & Train station & & $x$ & B & Re-planning the process sequence & construction site \\
\hline & $\begin{array}{l}\text { Use of fixed } \\
\text { buffers }\end{array}$ & & $\mathrm{x}$ & B & $\begin{array}{l}\text { Making use of buffers (slack) at the } \\
\text { end of a sequence/train }\end{array}$ & $\begin{array}{l}\text { Slack is used up, the } \\
\text { construction process is } \\
\text { stabilised }\end{array}$ \\
\hline & $\begin{array}{l}\text { Work package } \\
\text { acceleration }\end{array}$ & & $\mathrm{x}$ & B & $\begin{array}{l}\text { Targeting optimisatio } \\
\text { packages within a we }\end{array}$ & $\begin{array}{l}\text { Optimisatic } \\
\text { sequence }\end{array}$ \\
\hline & $\begin{array}{l}\text { Work package } \\
\text { shift }\end{array}$ & & $\mathrm{x}$ & B & $\begin{array}{l}\text { Reallocation c } \\
\text { another wagg }\end{array}$ & $\begin{array}{l}\text { Optimisation of the } \\
\text { sequence }\end{array}$ \\
\hline & Waggon switch & $x$ & $\mathrm{x}$ & C & $\begin{array}{l}\text { Swapping the position of at least two } \\
\text { waggons in the process sequence }\end{array}$ & $\begin{array}{l}\text { Optimisation of the process } \\
\text { sequence }\end{array}$ \\
\hline & $\begin{array}{l}\text { Division of } \\
\text { materials/logistic } \\
\mathrm{s}\end{array}$ & $x$ & $(\mathrm{X})$ & C & $\begin{array}{l}\text { Decoupling of value creating and } \\
\text { logistical tasks }\end{array}$ & Focus on the value chain \\
\hline & Waggon & & $\mathrm{x}$ & C & $\begin{array}{l}\text { Moving a waggon to a different } \\
\text { position in the process sequence }\end{array}$ & $\begin{array}{l}\text { Optimisation of the process } \\
\text { sequence }\end{array}$ \\
\hline & $\begin{array}{l}\text { Work packa } \\
\text { switch }\end{array}$ & & $x$ & C & $\begin{array}{l}\text { Swapping work packages between } \\
\text { waggons }\end{array}$ & $\begin{array}{l}\text { Optimisation of the process } \\
\text { sequence }\end{array}$ \\
\hline
\end{tabular}

\section{SELECted Adjustment MeChanisms}

\subsection{Overview}

The following section will describe the Category A adjustment mechanisms more in detail. These are according to the authors' experience the most frequently used ones. This covers the adjustment mechanisms for the decoupling of Takt areas, empty waggons, phase interlinking, soft start and train stoppage. These mechanisms are illustrated in charts, where the X-axis shows weekly Takts beginning with W1 and the Y-axis shows Takt areas beginning with TA 1.

\subsection{Decoupling of a Takt area}

If individual Takt areas cannot be completed to follow the order of the train, they can be decoupled and reallocated. For example, when planning is not fully completed or approved for a certain area, when the client changing its requirements, when materials are not ready or when approvals are still awaited. This mechanism is implemented the same way as in production industries, for instance when a car is reallocated back into the production line at a later stage. In the following example the client's decision has not been made in Takt area TA 2 and the Takt area is reallocated after TA 5. According to the one-week-Takt this means that the necessity of the decision-making can be delayed by three weeks. 


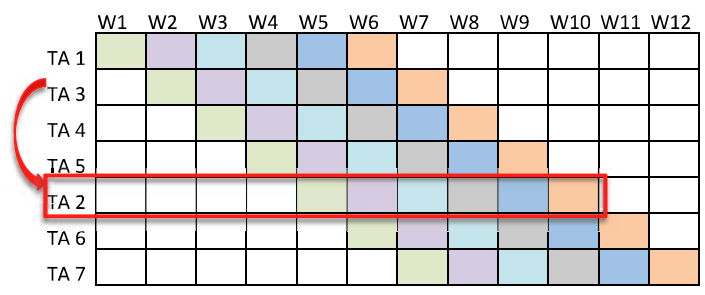

Figure 2: TA 2 is reallocated next to TA 5.

\subsection{Buffer waggons}

A buffer waggon is a planned buffer, which can ensure stability in certain situations. It can be implemented to account for drying times. A classic example would be after the screed waggon or if a problem is spotted during Takt Control. The completion and throughput time are increased by the time period of one Takt by adding an empty waggon.

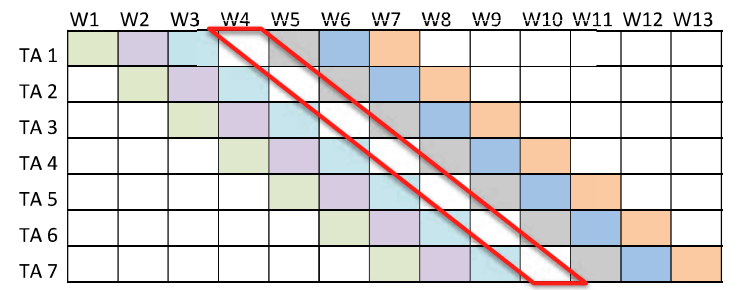

Figure 3: Inclusion of an empty waggon in the middle of the train

\subsection{Phase interlinking}

A typical construction project is divided into phases such as the division between designing and execution phase or shell and fit-out works. The goal of this mechanism is to reach a very close interlinking and the proper selection of the same batch size and Takt time. This means the gradient of each parallelogram in Figure 4 is equal. In many cases this might not be possible. Therefore, the goal is to reduce the amount of slack (empty spaces in the production plan) to increase the efficiency of the project. In the following example a batch size of two TAs and a Takt time of two weeks is anticipated for the shell construction (phase 1). In the second phase of construction the size is one week for each waggon and Takt area. The speed of construction can be interlinked, even with slack.

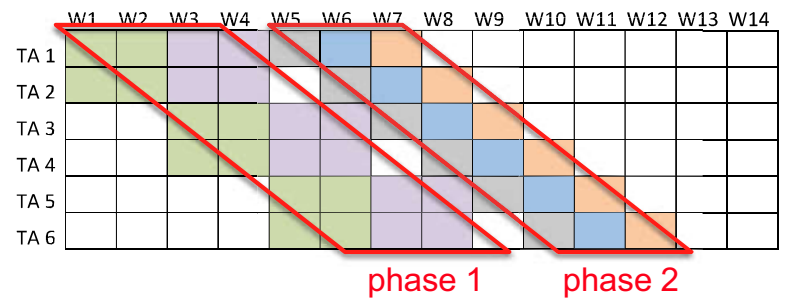

Figure 4: Interlinking of Phase 1 and Phase 2 


\subsection{Soft start}

If multiple trains are used, the choice between a soft and a hard start is possible. A soft start means that not all trains start at the same time. This allows one to collect experience from the first train and use it for the start of the second train. A disadvantage is the fluctuation of manpower in the starting phase as well as slow start of the construction site.

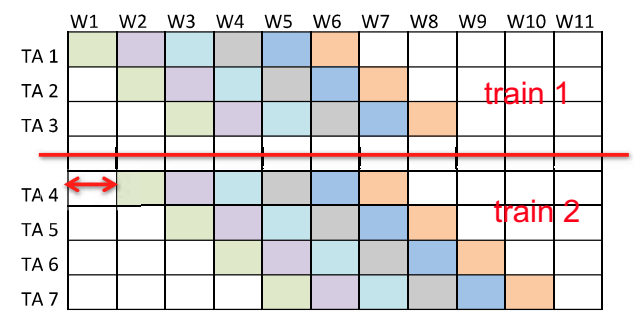

Figure 5: Example of the soft start of train 2

\subsection{Train stoppage}

Train stoppage leads to a disruption of the construction process. The reason for this is the occurrence of a problem that is not immediately solvable (i.e. within the Takt).

This type of disruption means that the entire train must be stopped until a sustainable solution has been found. Hence the disruption and its resolution are given the necessary attention. This mechanism is comparable to stopping the conveyor belt in production industries. In this Takt the catch-up works of disruptions are planned so that the train can continue with the next Takt. The construction process is only restarted once a sustainable solution has been found.

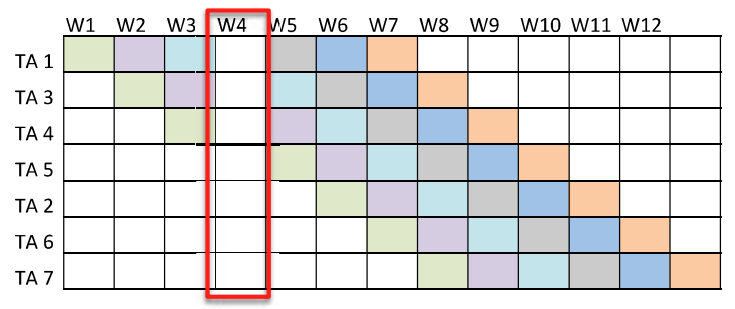

Figure 6: Train stoppage in Week 4.

\section{CONCLUSION AND OUTLOOK}

This article challenges previous theories by enabling an unprecedented level of flexibility while implementing the Takt Planning and Takt Control methods during the designing and execution phases of construction projects. The 31 adjustment mechanisms identified show the variety and flexibility of the methodology. By describing the five mechanisms of decoupling the Takt area, buffer waggons, phase interlinking, soft start and train stoppage the flexibility of the method is shown. In addition by presenting a formula for the calculation of the throughput and completion time a quantitative performance measurement is introduced.

It has to be noted that this article covers an initial compilation of adjustment mechanisms gathered from the authors' own projects. The list must therefore not be viewed as exhaustive. Future additions and further investigation are necessary. 


\section{REFERENCES}

Binninger, M.; Dlouhy, J.; Oprach, S.; Haghsheno, S. (2016): Methods for Production Leveling - Transfer from Lean Production to Lean Construction. In: $24^{\text {th }}$ Annual Conference of the International Group for Lean Construction 2016, Boston.

Binninger, M.; Dlouhy, J.; Haghsheno, S. (2017): Technical Takt Planning and Takt Control in Construction, $25^{\text {th }}$ Annual Conference of the International Group for Lean Construction 2017, Heraklion.

Dlouhy, J. , Binninger, M. , Oprach, S. \& Haghsheno, S. 2016, 'Three-Level Method of Takt Planning and Takt Control - a New Approach for Designing Production Systems in Construction' In: $24^{\text {th }}$ Annual Conference of the International Group for Lean Construction. Boston, USA, 20-22 Jul 2016.

Haghsheno, S.; Binninger, M.; Dlouhy, J.; Oprach, S. (2016): History and theoretical Foundations of Takt Planning and Takt Control. IGLC Conference 2016, Boston.

Hao, Q.; Shen, W.; Neelamkavil, J.; Thomas, R. (2008): Change Management in Construction Projects. Proceedings of the CIB W78 25th International Conference on Information Technology: Improving the Management of Construction Projects Through IT Adoption, Santiago, Chile.

Park, M.; Pena-Mora, F. (2003): Dynamic Change Management for Construction: introducing the Change Cycle into Model-based Project Management. Online: Wiley InterScience.

Seppänen, O. 2012, 'A Production Control Game for Teaching of Location-Based Management System's Controlling Methods' In:, Tommelein, I.D. \& Pasquire, C.L., 20th Annual Conference of the International Group for Lean Construction. San Diego, USA.

Syben, G. (2014): Bauleitung im Wandel - Arbeit als Bewältigung von Kontingenz. (Changes in Construction Site Management - Work for handling contingency). Edition Sigma.

Zimmermann, G.; Skambraks, J. (2012): Sofortwissen kompakt: KVP. (Knowledge instantly: CIP). Heragon Verlag. 